\title{
Bacterial Isolates From Patients With Preterm Labor With and Without Preterm Rupture of the Fetal Membranes
}

\author{
H. Mikamo,* Y. Sato, Y. Hayasaki, K. Kawazoe, Y.X. Hua, and \\ T. Tamaya \\ Department of Obstetrics and Gynecology, School of Medicine, Gifu University, Gifu, Japan
}

\begin{abstract}
Objective: The aim of this study is to describe the bacterial flora of women in preterm labor with or without premature rupture of membranes.

Methods: Retrospective studies of 239 patients with preterm labor were performed.

Results: One hundred and twenty-three of 239 patients with preterm labor $(51.5 \%)$ had bacterial vaginosis. Seventy of the 239 patients with preterm labor $(29.3 \%)$ developed premature rupture of the membranes (preterm PROM). Of the 70 patients with preterm PROM, 51 (72.9\%) had bacterial vaginosis. Therefore, 51 of the 123 patients with bacterial vaginosis $(41.5 \%)$ developed preterm PROM. An increased number of organisms detected from the vaginal discharge in patients with preterm labor was associated with preterm PROM by Cochran-Armitage test. An increased number of organisms detected from the vaginal discharge in patients with preterm labor complicated with bacterial vaginosis was significantly associated with preterm PROM by Cochran-Armitage test.

Conclusions: In preterm labor, the number of different species detected in the vagina provide sensitive and specific prediction of preterm PROM in patients with preterm labor. Infect. Dis. Obstet. Gynecol. 7:190-194, 1999. @1999 Wiley-Liss, Inc.
\end{abstract}

preterm labor; preterm PROM; prediction; bacterial vaginosis

$\mathrm{P}$ reterm birth is the leading perinatal complication. ${ }^{1-3}$ Since intrauterine infection from organisms found in the genital tract has been implicated in both the etiology and adverse sequelae of preterm premature rupture of the membranes (preterm PROM),${ }^{3-6}$ culturing the vagina has not been an essential part of clinical management. Although there are many studies that evaluate such cultures in the prediction of intrauterine pregnancies, they have been focused on the identification of bacteria. ${ }^{4-6}$ The aim of this study is to investigate the significance of bacterial culture in predicting preterm PROM in patients with preterm labor.

\section{MATERIALS AND METHODS Subjects}

From 1992 to 1996, we sampled the vaginal discharge of 239 patients with preterm labor that were referred to the hospital of the School of Medicine of Gifu University for further assessment. The patients were Japanese married women of middleclass socioeconomic status who had had no sexual intercourse in the past 10 days, had no history of sexual transmitted diseases, and had taken no antibiotic therapy during pregnancy. Patients with chlamydia, trichomoniasis, or candidiasis infection were excluded from the study. Consent to the

*Correspondence to: Hiroshige Mikamo, MD, PhD, Department of Obstetrics and Gynecology, School of Medicine, Gifu University, 40, Tsukasa-machi, Gifu-city, Gifu 500-8705, Japan. E-mail: mikamo@cc.gifu-u.ac.jp 
study was obtained from the patients and the committee of the institution.

\section{Diagnosis of Bacterial Vaginosis}

Bacterial vaginosis was diagnosed with intact membranes in 239 patients by the presence of the following four criteria: ${ }^{7-10}$ thin and homogenous vaginal discharge, vaginal $\mathrm{pH}$ above 4.5 , positive amine "whiff" test, and the presence of clue cells in wetmount preparations of vaginal discharges.

\section{Sampling Method}

Vaginal discharge was collected from the posterior vaginal fornix with a sterilized cotton wool swab, which gathers $0.05 \mathrm{~mL}$ of sample per swab.

\section{Culture Methods}

Immediately after collection, the swab, specimen $(0.05 \mathrm{~mL})$ was suspended in $5 \mathrm{~mL}$ of the anaerobic diluent for culture. ${ }^{8-11}$ The composition of the anaerobic buffer was as follows: $4 \mathrm{~g}$ of $\mathrm{KH}_{2} \mathrm{PO}_{4}, 6 \mathrm{~g}$ of $\mathrm{Na}_{2} \mathrm{HPO}_{4}, 1 \mathrm{~g}$ of L-cysteine-HCl-H2O, $1 \mathrm{~g}$ of Tween 80 (Sigma, St. Louis, MO), and agar, and $1,000 \mathrm{~mL}$ of distilled water with a $\mathrm{pH}$ of 7.2. All the components were mixed in a solution and heated at $80^{\circ} \mathrm{C}$ for 30 minutes. All tubes were sterilized in an autoclave at $115^{\circ} \mathrm{C}$ for 20 minutes. A 9-mL aliquot of the buffer was transferred to each test tube, air in the tube was immediately replaced with $\mathrm{CO}_{2}$, and the tube was sealed with a butyl rubber stopper.

After samples were suspended in the buffer, the tubes were resealed under a continuous stream of $\mathrm{CO}_{2}$ gas of commercial grade to drive air out. Exposure of samples to atmospheric oxygen was restricted to 5 minutes or less. Incubation commenced immediately after a sample was suspended in a solution. A small aliquot for the subsequent culture was aspirated with a syringe via a butyl rubber stopper.

For quantitative bacterial determination, serial dilutions were made with the anaerobic buffer. The time lag from the specimen collection to the quantitative determination was within 1 hour.

Staphylococcus-selective agar (Nissui Pharmaceutical Co. Ltd., Tokyo, Japan) and MacConkey agar (Becton Dickinson and Co., Cockeysville, MD) were used for aerobic culture. Sheep blood agar (Becton Dickinson) and chocolate agar (Becton Dickinson) were used for $\mathrm{CO}_{2}$ culture.
As for Gardnerella vaginalis, human bloodbilayer-Tween (HB'T) medium, developed by Totten et al., ${ }^{12}$ was used for $\mathrm{CO}_{2}$ culture. It consists of a bottom layer of Columbia colistin-nalidixic acid agar (Becton Dickinson) supplemented with $1 \%$ Proteose Peptone no. 3 (Difco Laboratories, Detroit, MI), amphotericin B $(2.0 \mu \mathrm{g} / \mathrm{mL})$, and $0.0075 \%$ Tween 80 (Becton Dickinson) and a top layer of the same composition with $5 \%$ human blood added.

For anaerobic culture, Brucella HK (hemin, vitamin K1) RS (rabbit, sheep) blood agar (Kyokuto Pharmaceutical Co. Ltd., Tokyo, Japan) was used as a nonselective medium; -phenylethylalcohol (PEA) Brucella HK blood agar (Kyokuto), paromomycin/vancomycin (PV) Brucella HK blood agar (Kyokuto) and Bacteroides bile esculin (BBE) agar (Kyokuto) were used as selective media. Sabouraud dextrose agar (Becton Dickinson) was used for fungal culture.

Aerobic culture was performed at $37^{\circ} \mathrm{C}$ for 2 days, $\mathrm{CO}_{2}$ culture in $5 \% \mathrm{CO}_{2}$ in air at $37^{\circ} \mathrm{C}$ for 3 days, anaerobic culture in a GasPak Pouch at $37^{\circ} \mathrm{C}$ for 7 days, and fungal culture at $37^{\circ} \mathrm{C}$ for 7 days.

\section{Bacterial Identification}

Each colony with an individual appearance on an agar plate was subcultured three times on a nonselective medium to obtain a pure culture for bacterial identification. ${ }^{8-11}$ Among aerobes, grampositive and catalase-positive cocci were identified by Api STAPH identification system (bioMerieux SA, Marcy l'Etoile, France). Gram-positive and catalase-negative cocci were identified by Api STREP identification system (bioMerieux SA), and gram-negative rods were identified by Enterotube II (Becton Dickinson) or Oxi/Ferm Tube II (Becton Dickinson). Haemophilus species and $G$. vaginalis were identified by Rap ID NH (Innovative Diagnostic System, Inc., Atlanta, GA).

Anaerobic bacteria were identified by Rap ID ANA System II (Innovative Diagnostic System). For identification of Mobiluncus spp., colonial characteristics were observed and a Gram stain was performed. Gram-negative or gram-variable curved rods were identified by Rap ID ANA System II. Nitrate reduction and hippuric acid hydrolysis tests were used for identification at the subspecies level. Fungi were identified by Api AUXANOGRAM (bioMerieux SA). 
TABLE I. The number of different species detected in all patients with preterm labor and those who developed preterm PROM

\begin{tabular}{ccc}
\hline $\begin{array}{c}\text { Number of } \\
\text { organisms detected }\end{array}$ & $\begin{array}{c}\text { Preterm labor } \\
(\%)\end{array}$ & $\begin{array}{c}\text { Preterm PROM } \\
(\%)\end{array}$ \\
\hline 0 & $0(0)$ & $0(0)$ \\
1 & $4(1.7)$ & $0(0)$ \\
2 & $16(6.7)$ & $0(0)$ \\
3 & $34(14.2)$ & $3(4.3)$ \\
4 & $92(38.5)$ & $26(37.1)$ \\
5 & $58(24.3)$ & $22(31.4)$ \\
6 & $24(10.0)$ & $11(15.7)$ \\
7 & $9(3.8)$ & $6(8.6)$ \\
8 & $2(0.8)$ & $2(2.9)$ \\
Total & 239 & 70 \\
\hline
\end{tabular}

\section{Statistical Analysis}

All results were analyzed using the CochranArmitage test.

\section{RESULTS}

One hundred and twenty-three of 239 patients with preterm labor $(51.5 \%)$ had bacterial vaginosis. Seventy in 239 patients with preterm labor (29.3\%) developed preterm PROM. Of the 70 patients with preterm PROM, 51 (72.9\%) had bacterial vaginosis. Therefore, 51 in 123 patients with preterm labor complicated with bacterial vaginosis $(41.5 \%)$ reduced preterm PROM. The cultures from the lower genital tract in patients with preterm labor were positive in all specimens.

The number of different species detected from the vaginal discharge in all 239 patients with preterm labor and the 70 patients with preterm PROM following preterm labor are shown in Table 1. An increase in the number of organisms detected from the vaginal discharge in patients with preterm labor was significantly associated with preterm PROM by Cochran-Armitage test $\left(P=2.6 \times 10^{-8}\right)$.

Table 2 shows the number of different species detected from the vaginal discharge in the $123 \mathrm{pa}-$ tients with bacterial vaginosis and the 51 patients with both preterm PROM following preterm labor and bacterial vaginosis. An increase in the number of organisms detected in the vaginal discharge of patients with preterm labor complicated with bacterial vaginosis was significantly associated with preterm PROM by Cochran-Armitage test $(P=$ $0.0030)$.

The organisms isolated from the vaginal discharge in patients with preterm labor are listed in
TABLE 2. The number of different species detected in all patients with preterm labor and bacterial vaginosis $(\mathrm{BV})$ and those with preterm PROM

\begin{tabular}{ccc}
\hline $\begin{array}{c}\text { Number of } \\
\text { organisms detected }\end{array}$ & $\begin{array}{c}\text { Preterm labor } \\
\text { and BV (\%) }\end{array}$ & $\begin{array}{c}\text { Preterm PROM } \\
\text { and BV (\%) }\end{array}$ \\
\hline 0 & $0(0)$ & $0(0)$ \\
1 & $0(0)$ & $0(0)$ \\
2 & $1(0.8)$ & $0(0)$ \\
3 & $4(3.3)$ & $1(2.0)$ \\
4 & $48(39.0)$ & $16(31.4)$ \\
5 & $40(32.5)$ & $17(33.3)$ \\
6 & $20(16.3)$ & $9(17.6)$ \\
7 & $8(6.5)$ & $6(11.2)$ \\
8 & $2(1.6)$ & $2(4.0)$ \\
Total & 123 & 51 \\
\hline
\end{tabular}

Table 3. The dominant organisms detected were Staphylococcus haemolyticus, Streptococcus agalactiae, Escherichia coli, Fusobacterium nucleatum, and Prevotella bivia. However, the particular organisms for preterm labor were not specified.

The organisms isolated from the vaginal discharge in patients with preterm PROM following preterm labor are listed in Table 4. The dominant organisms detected were $S$. haemolyticus, $S$. agalactiae, E. coli, F. nucleatum, and P. bivia. However, the particular organisms for preterm PROM were not specified.

\section{DISCUSSION}

Recent studies have reported the relation between preterm PROM and bacterial vaginosis; $;^{3-5,11}$ this condition is characterized by depletion of vaginal Lactobacilli with increased $G$. vaginalis in association with such organisms as Bacteroides species, Prevotella species, Peptostreptococcus species, and Mycoplasma species. ${ }^{7-11}$ This study suggests that the increased number of organisms detected from the vaginal discharge might be predictive of the prevalence of preterm labor and preterm PROM. This means that the number of organisms detected in the vagina provides sensitive and specific prediction of intrauterine infection with aerobic or anaerobic organisms in pregnancies with preterm PROM. Most studies associated with vaginal flora in pregnancies have found that it is the relative quantity of organisms. ${ }^{3-5,11}$ However, great efforts are needed in the quantitative assays. Therefore, we gave attention to the numbers of different species detected.

In most cases with positive amniotic fluid cul- 
TABLE 3. Organisms detected from the vaginal discharge of patients with preterm labor

\begin{tabular}{|c|c|c|}
\hline Bacteria & $\begin{array}{l}\text { Number of } \\
\text { strains }\end{array}$ & $\begin{array}{c}\% \text { of total } \\
(1019)\end{array}$ \\
\hline Aerobe & 558 & 54.8 \\
\hline Gram-positive cocci & 290 & 28.5 \\
\hline Staphylococcus aureus & 16 & 1.6 \\
\hline Staphylococcus epidermidis & 49 & 4.8 \\
\hline Staphylococcus haemolyticus & 21 & 2.1 \\
\hline Staphylococcus hominis & 3 & 0.3 \\
\hline Staphylococcus simulans & 5 & 0.5 \\
\hline Staphylococcus xylosus & 2 & 0.2 \\
\hline Staphylococcus spp. & 5 & 0.5 \\
\hline Streptococcus agalactiae & 70 & 6.9 \\
\hline Streptococcus bovis & 3 & 0.3 \\
\hline Streptococcus oralis & 7 & 0.7 \\
\hline Streptococcus pyogenes & 8 & 0.8 \\
\hline Streptococcus sanguis & 5 & 0.5 \\
\hline Streptococcus spp. & 5 & 0.5 \\
\hline Enterococcus avium & 4 & 0.4 \\
\hline Enterococcus faecalis & 54 & 5.3 \\
\hline Enterococcus faecium & 20 & 2 \\
\hline Gemella morbillorum & 5 & 0.5 \\
\hline Gram-positive cocci & 8 & 0.8 \\
\hline Gram-positive bacilli & 107 & 10.5 \\
\hline Gardnerella vaginalis & 100 & 9.8 \\
\hline Gram-positive bacilli & 7 & 0.7 \\
\hline Gram-negative bacilli & 161 & 15.8 \\
\hline Burkholderia cepacia & 8 & 0.8 \\
\hline Enterobacter cloacae & 15 & 1.5 \\
\hline Escherichia coli & 88 & 8.6 \\
\hline Klebsiella pneumoniae & 24 & 2.4 \\
\hline Proteus mirabilis & 7 & 0.7 \\
\hline Proteus vulgaris & 7 & 0.7 \\
\hline Pseudomonas aeruginosa & 9 & 0.9 \\
\hline Gram-negative bacilli & 3 & 0.3 \\
\hline Anaerobe & 461 & 45.2 \\
\hline Gram-positive cocci & 133 & 13.1 \\
\hline Peptostreptococcus anerobius & 46 & 4.5 \\
\hline Peptostreptococcus asaccharolyticus & 5 & 0.5 \\
\hline Peptostreptococcus magnus & 42 & 4.1 \\
\hline Peptostreptococcus micros & 27 & 2.6 \\
\hline Peptostreptococcus prevotil & 5 & 0.5 \\
\hline Peptostreptococcus tetradius & 3 & 0.3 \\
\hline Peptostreptococcus spp. & 5 & 0.5 \\
\hline Gram-positive bacilli & 129 & 12.7 \\
\hline Mobiluncus curtisii subsp. curtisii & 48 & 4.7 \\
\hline Mobiluncus curtisii subsp. holmesii & 36 & 3.5 \\
\hline Mobiluncus mulieris & 45 & 4.4 \\
\hline Gram-negative bacilli & 199 & 19.5 \\
\hline Bacteroides distasonis & 5 & 0.5 \\
\hline Bacteroides fragilis & 31 & 3 \\
\hline Bacteroides thetaiotaomicron & 15 & 1.5 \\
\hline Bacteroides uniformis & 2 & 0.2 \\
\hline Bacteroides spp. & 5 & 0.5 \\
\hline Fusobacterium nucleatum & 31 & 3 \\
\hline Prevotella bivia & 61 & 6 \\
\hline Prevotella buccae & 2 & 0.2 \\
\hline Prevotella disiens & 25 & 2.5 \\
\hline Prevotella intermedia & 5 & 0.5 \\
\hline Prevotella melaninogenica & 5 & 0.5 \\
\hline Prevotella oralis & 5 & 0.5 \\
\hline Prevotella spp. & 4 & 0.4 \\
\hline Gram-negative bacilli & 4 & 0.4 \\
\hline Total & 1019 & \\
\hline
\end{tabular}

TABLE 4. Organisms detected from the patients with preterm PROM

\begin{tabular}{|c|c|c|}
\hline Bacteria & $\begin{array}{c}\text { Number of } \\
\text { strains }\end{array}$ & $\begin{array}{c}\% \text { of total } \\
(801) \\
\end{array}$ \\
\hline Aerobe & 448 & 55.9 \\
\hline Gram-positive cocci & 232 & 29 \\
\hline Staphylococcus aureus & 12 & 1.5 \\
\hline Staphylococcus epidermidis & 39 & 4.9 \\
\hline Staphylococcus haemolyticus & 17 & 2.1 \\
\hline Staphylococcus hominis & 2 & 0.2 \\
\hline Staphylococcus simulans & 4 & 0.5 \\
\hline Staphylococcus xylosus & 2 & 0.2 \\
\hline Staphylococcus spp. & 4 & 0.5 \\
\hline Streptococcus agalactiae & 58 & 7.2 \\
\hline Streptococcus bovis & 3 & 0.3 \\
\hline Streptococcus oralis & 5 & 0.6 \\
\hline Streptococcus pyogenes & 7 & 0.9 \\
\hline Streptococcus sanguis & 3 & 0.4 \\
\hline Streptococcus spp. & 3 & 0.4 \\
\hline Enterococcus avium & 3 & 0.4 \\
\hline Enterococcus faecalis & 44 & 5.5 \\
\hline Enterococcus faecium & 16 & 2.0 \\
\hline Gemella morbillorum & 4 & 0.5 \\
\hline Gram-positive cocci & 6 & 0.7 \\
\hline Gram-positive bacilli & 85 & 10.6 \\
\hline Gardnerella vaginalis & 80 & 10.0 \\
\hline Gram-positive bacilli & 5 & 0.6 \\
\hline Gram-negative bacilli & 131 & 16.4 \\
\hline Burkholderia cepacia & 6 & 0.7 \\
\hline Enterobacter cloacae & 13 & 1.6 \\
\hline Escherichia coli & 70 & 8.7 \\
\hline Klebsiella pneumoniae & 21 & 2.6 \\
\hline Proteus mirabilis & 5 & 0.6 \\
\hline Proteus vulgaris & 6 & 0.7 \\
\hline Pseudomonas aeruginosa & 8 & 1.0 \\
\hline Gram-negative bacilli & 2 & 0.2 \\
\hline \multicolumn{3}{|l|}{ Anaerobe } \\
\hline Gram-positive cocci & 107 & 13.4 \\
\hline Peptostreptococcus anaerobius & 37 & 4.6 \\
\hline Peptostreptococcus asaccharolyticus & 4 & 0.5 \\
\hline Peptostreptococcus magnus & 34 & 4.2 \\
\hline Peptostreptococcus micros & 22 & 2.7 \\
\hline Peptostreptococcus prevotii & 4 & 0.5 \\
\hline Peptostreptococcus tetradius & 3 & 0.4 \\
\hline Peptostreptococcus spp. & 3 & 0.4 \\
\hline Gram-positive bacilli & 106 & 13.2 \\
\hline Mobiluncus curtisii subsp. curtisii & 42 & 5.2 \\
\hline Mobiluncus curtisii subsp. holmesii & 27 & 3.4 \\
\hline Mobiluncus mulieris & 37 & 4.6 \\
\hline Gram-negative bacilli & 140 & 17.5 \\
\hline Bacteroides distasonis & 4 & 0.5 \\
\hline Bacteroides fragilis & 27 & 3.4 \\
\hline Bacteroides thetaiotaomicron & 12 & 1.5 \\
\hline Bacteroides uniformis & 2 & 0.2 \\
\hline Bacteroides spp. & 4 & 0.5 \\
\hline Fusobacterium nucleatum & 1 & 0.1 \\
\hline Prevotella bivia & 51 & 6.4 \\
\hline Prevotella buccae & 2 & 0.2 \\
\hline Prevotella disiens & 19 & 2.4 \\
\hline Prevotella intermedia & 4 & 0.5 \\
\hline Prevotella melaninogenica & 4 & 0.5 \\
\hline Prevotella oralis & 4 & 0.5 \\
\hline Prevotella spp. & 3 & 0.4 \\
\hline Gram-negative bacilli & 3 & 0.4 \\
\hline Total & 801 & 100 \\
\hline
\end{tabular}


tures, the same organisms were recovered from vaginal swabs. ${ }^{11}$ This finding is compatible with the hypothesis that the lower genital tract is the source of the offending organisms in intrauterine infection associated with preterm labor.

Most bacteria responsible for ascending infections are derived from the indigenous genital flora. ${ }^{11}$ Anaerobic bacteria are of major importance. ${ }^{11}$ Many of these anaerobes are considered potentially pathogenic, as they have been frequently isolated in patients with genital infections. ${ }^{5-6,11}$ Genera such as the anaerobic cocci, Bacteroides spp., Prevotella spp., and Fusobacterium spp. have been implicated in maternal or neonatal infections accompanying premature labor or PROM. ${ }^{5-6,11}$

In a matched case-control study of 54 consecutive women in preterm labor, Gravett et al. ${ }^{13}$ found a significant association between bacterial vaginosis and preterm labor $(43 \%$ of study patients versus $14 \%$ of control patients, $P=0.02$, relative risk ratio of 3.80). Martius et al. ${ }^{14}$ performed a similar study at the same center using Gram stain to diagnose bacterial vaginosis and had similar findings. Bacterial vaginosis was significantly associated with preterm labor (odds ratio of 2.3), as was the presence of Chlamydia trachomatis and the absence of Lactobacilli species. In this study, $70 \%$ of women with preterm labor had PROM.

The results of our study add to the existing evidence that bacterial vaginosis is an independent risk factor for preterm birth and suggest that the timing of this infection in gestation significantly affects this risk. It remains to be shown whether this association is causative or whether bacterial vaginosis is associated with some as yet unidentified factor that initiates preterm labor and birth. Although bacterial vaginosis is commonly found in pregnant women, preterm birth usually does not occur in these pregnancies. In addition, it remains unclear whether treatment of pregnant women with bacterial vaginosis decreases their risk of preterm birth. A large, well-controlled, randomized trial of treatment for bacterial vaginosis in pregnancy is needed to answer this question.

\section{REFERENCES}

1. Rush RW, Kierse MJ, Howat P. The contribution of preterm labour to perinatal mortality. BMJ 1976;2:965968.

2. Morrison J. Preterm birth: a puzzle worth solving. Obstet Gynecol 1990;76:5-12.

3. James D. Preterm prelabour rupture of membranes. Arch Dis Child 1991;66:812-815.

4. Romero R, Mazor M, Wu YK, et al. Infection in the pathogenesis of preterm labor. Semin Perinatol 1988;12: 262-279.

5. Kurki T, Sivonen A, Renkonen O, Savia E, Ylikorkala $\mathrm{O}$. Bacterial vaginosis in early pregnancy and pregnancy outcome. Obstet Gynecol 1992;80:173-177.

6. Hay PE, Lamont RF, Taylor-Robinson D, Morgan DJ, Ison C, Pearson J. Abnormal bacterial colonisation of the genital tract and subsequent preterm delivery and late miscarriage. BMJ 1994;308:295-298.

7. Spiegel CA, Davick P, Totten PA, et al. Gardnerella vaginalis and anaerobic bacteria in the etiology of bacterial (nonspecific) vaginosis. Scand J Infect Dis Suppl 1983;40:41-46.

8. Mikamo H, Izumi K, Ito K, et al. Study on treatment of bacterial vaginosis with oral administration of metronidazole or cefdinir. Chemotherapy 1994;40:362-368.

9. Mikamo H, Kawazoe K, Izumi K, et al. Bacteriological epidemiology and treatment of bacterial vaginosis. Chemotherapy 1996;42:78-84.

10. Mikamo H, Kawazoe K, Izumi K, Watanabe K, Ueno K Tamaya T. Comparative study on vaginal or oral treatment of bacterial vaginosis. Chemotherapy 1997;43:6068.

11. Mikamo H, Kawazoe K, Sato Y, Izumi K, Tamaya T. Studies on the clinical implications of anaerobes, especially Prevotella bivia, in obstetrics and gynecology. J Infect Chemother 1998;4:177-187.

12. Totten PA, Amsel R, Hale J, Piot P, Holmes KK. Selective differential human blood bilayer media for isolation of Gardnerella (Haemophilus) vaginalis. J Clin Microbiol 1982;15:141-147.

13. Gravett MG, Hummel D, Eschenbach DA, Holmes KK. Preterm labor associated with subclinical amniotic fluid infection with bacterial vaginosis. Obstet Gynecol 1986; 67:229-237.

14. Martius J, Krohn MA, Hillier SL, Stamm WE, Holmes KK, Eschenbach DA. Relationship of vaginal Lactobacillus species, cervical Chlamydia trachomatis, and bacterial vaginosis to preterm birth. Obstet Gynecol 1988;76: 89-95. 


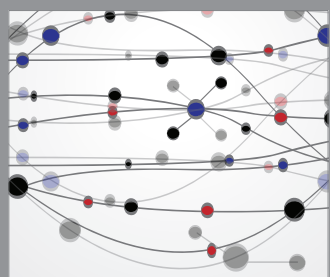

The Scientific World Journal
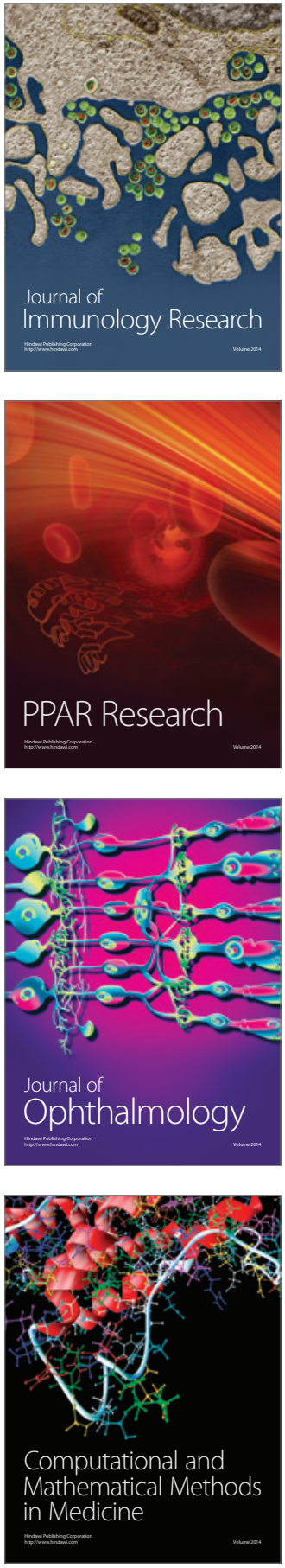

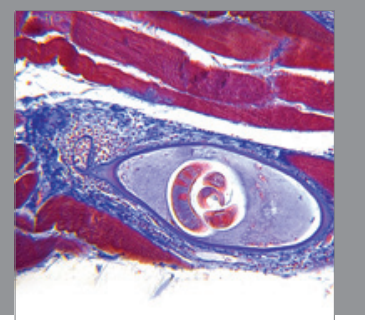

Gastroenterology

Research and Practice
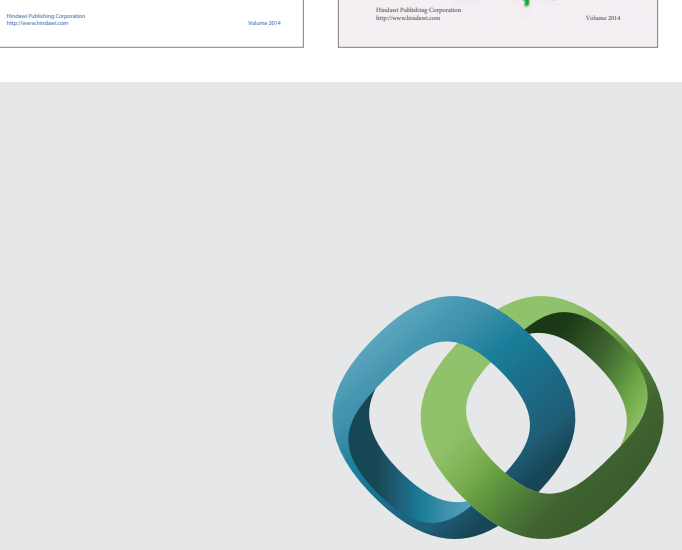

\section{Hindawi}

Submit your manuscripts at

http://www.hindawi.com
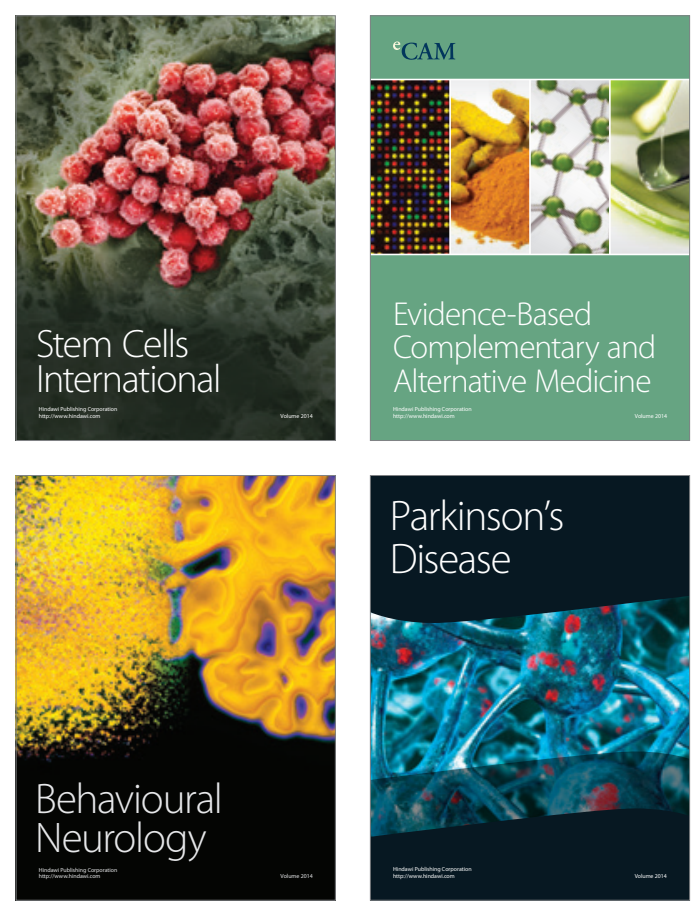

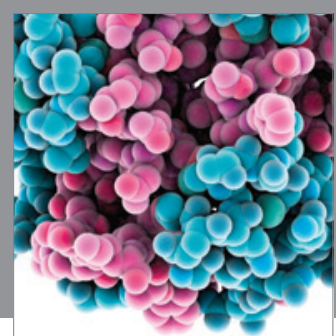

Journal of
Diabetes Research

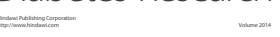

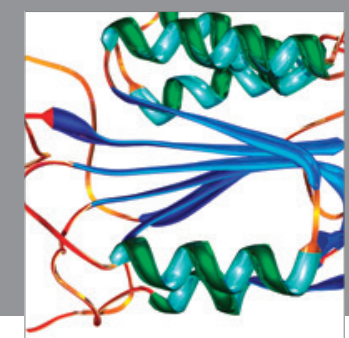

Disease Markers
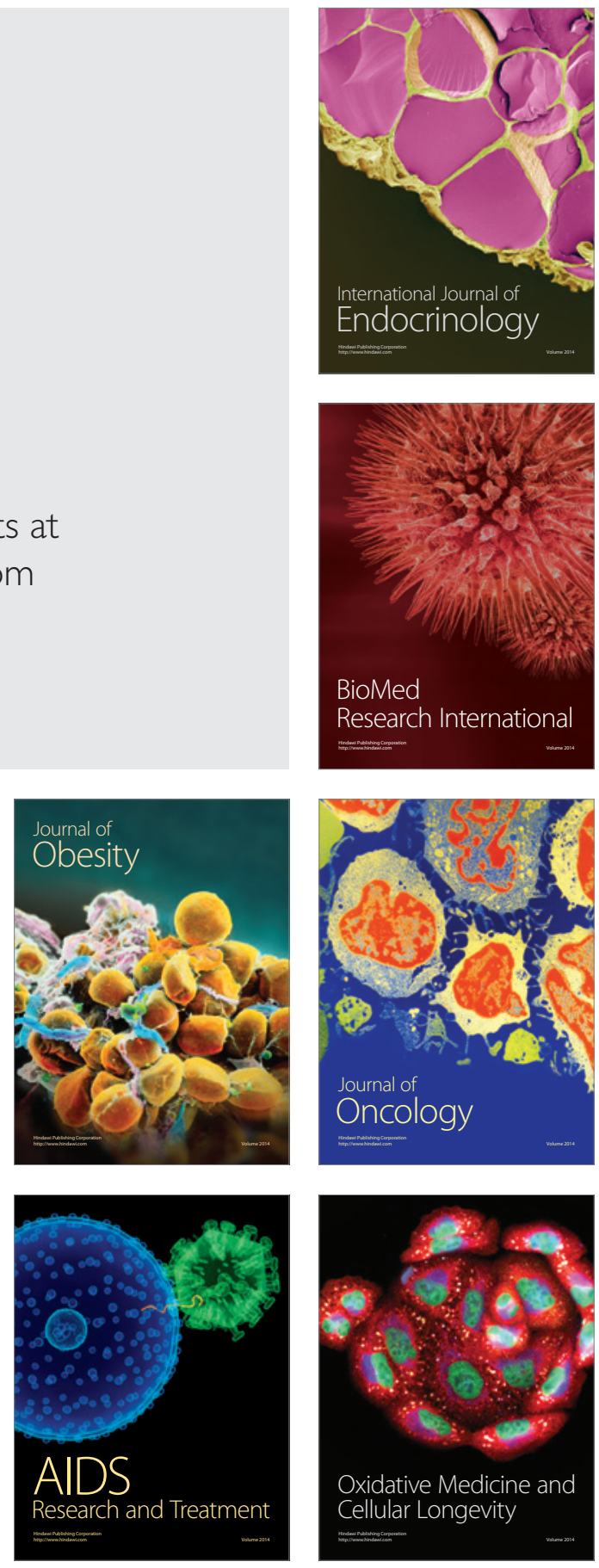